\title{
ANALISIS STABILITAS LERENG DAN PENANGGULANGAN LONGSORAN MENGGUNAKAN PROGRAM PLAXIS V.8.2
}

\author{
Akhmad Gazali ${ }^{(1)}$ Abdurahim Sidiq ${ }^{(2)}$ Adhi Surya ${ }^{(3)}$ \\ (1), (3) Dosen Program Studi Teknik Sipil, Fatek, Universitas Islam Kalimantan MAB \\ ${ }^{(2)}$ Dosen Program Studi Teknik Mesin, Fatek, Universitas Islam Kalimantan MAB \\ E-mail: akhmadgazali51@gmail.com/Hp.+6285249529517
}

\begin{abstract}
ABSTRAK
Curah hujan yang tinggi akhir-akhir ini menyebabkan kondisi lereng yang secara berangsur-angsur mengalami kelongsoran, dimana terjadinya kelongsoran tersebut dapat membahayakan keselamatan masyarakat di sekitar jalan tersebut. Longsoran lereng pada penelitian ini terjadi di jalan Desa Gunung Ulin, Kecamatan Pulau Laut Utara, Kabupaten Kotabaru, Propinsi Kalimantan Selatan. Berdasarkan hasil penyelidikan tanah yang dilakukan pada daerah tersebut didominasi oleh jenis tanah lempung dengan kedalaman tanah keras mencapai 10,2 meter. Tujuan dari penelitian ini adalah untuk mengetahui analisis stabilitas lereng dan alternatif penanggulangan longsoran yang aman dengan bantuan Program PLAXIS V.8.2. Pengolahan data tanah dilakukan di lapangan dan laboratorium, kemudian dilakukan analisis stabilitas lereng dengan menggunakan metode Alan.W.Bishop. Untuk menentukan tekanan tanah aktif dan pasif digunakan metode Rankine. Hasil penelitian melalui analisis stabilitas lereng menggunakan Program PLAXIS V.8.2 menunjukkan bahwa kondisi awal lereng tidak aman dengan nilai Safety Factor (SF) sebesar 1,407. Untuk menanggulangi kelongsoran tersebut, digunakan alternatif pemasangan turap baja bentuk kotak jenis FSP VIL (Profil A dan B), dengan panjang total 10,7 meter dari permukaan tanah. Untuk menahan gaya lateral digunakan jangkar sepanjang 7,2 meter dengan diameter jangkar sebesar $3 \mathrm{~cm}$, sehingga diperoleh kondisi lereng menjadi aman dengan nilai SF sebesar 5,277.
\end{abstract}

Kata Kunci: Stabilitas Lereng, longsoran, PLAXIS V.8.2.

\begin{abstract}
ABSTACT
High rainfall lately causes slope conditions that gradually experience landslides, where the occurrence of these landslides can endanger the safety of the community around the road. Slope avalanches in this study occurred in the village of Gunung Ulin, Pulau Laut Utara District, Kotabaru Regency, South Kalimantan Province. Based on the results of soil investigations carried out in the area dominated by clay soil types with a depth of hard soils reaching 10.2 meters. The purpose of this study was to determine the analysis
\end{abstract}


JURNAL KACAPURI

JURNAL KEILMUAN TEKNIK SIPIL

Volume 3 Nomor 1 Edisi Juni 2020

of slope stability and alternative safe landslide countermeasures with the help of the PLAXIS V.8.2 Program. Soil data processing is carried out in the field and laboratory, then slope stability analysis is done using the Alan.W.Bishop method. To determine active and passive soil pressures the Rankine method is used. The results of the study through the analysis of slope stability using the PLAXIS V.8.2 Program showed that the initial conditions of the slope were not safe with a Safety Factor (SF) value of 1.407. To overcome these landslides, an alternative installation of box-shaped steel sheet pile type FSP VIL (Profiles A and B), with a total length of 10.7 meters above ground level. To hold the lateral force, an anchor length of 7.2 meters is used with an anchor diameter of $3 \mathrm{~cm}$, so that the slope condition is safe with an SF value of 5.277.

Keywords: Availability of Water, Debit, Rantau Baru Basin.

\section{PENDAHULUAN}

Dalam bidang Teknik Sipil, tanah merupakan dasar dari suatu pembangunan konstruksi. Tanah diharapkan dapat menahan pembebanan yang bekerja di atasnya. Perencanaan yang matang sangat diperlukan, guna menghasilkan suatu konstruksi yang stabil, aman dan ekonomis. Namun, tidak semua bangunan didirikan pada daerah yang memiliki permukaan yang datar, karena setiap daerah memiliki kondisi geografis dan geologi yang berbeda. Konstruksi yang dibangun pada daerah yang memiliki elevasi tanah yang lebih tinggi dari daerah sekitarnya, sangat rawan terhadap terjadinya kelongsoran. Tanah yang tidak datar akan menghasilkan komponen gravitasi dari berat, yang cenderung menggerakkan massa tanah dari elevasi tinggi ke elevasi yang lebih rendah. Longsoran yang terjadi akan membahayakan bangunan yang berdiri di atasnya.

Selain itu, keruntuhan tanah pada lereng atau longsoran umumnya disebabkan oleh penambahan beban pada lereng, penggalian, rembesan air dan/ infiltrasi air hujan. Keruntuhan dapat berlangsung dalam waktu yang relatif cepat, namun bisa juga terjadi secara berangsur-angsur. Salah satu contoh keruntuhan lereng yang terjadi, yaitu pada jalan di Desa Gunung Ulin, Kecamatan Pulau Laut Utara, Kabupaten Kotabaru yang menjadi tinjauan dalam penelitian ini.

Kondisi tanahnya berupa tanah lempung, dimana sangat dipengaruhi oleh kadar air. Kelongsoran terjadi pada musim hujan dengan intensitas air yang besar. Tanah menjadi jenuh dan bertambah berat, sehingga kuat geser tanah berkurang dan menambah gaya lateral tanah. Kondisi inilah yang menyebabkan longsornya tanah dan sangat memerlukan perhatian yang serius. Banyak metode yang bisa digunakan dalam mengatasi kelongsoran yang terjadi, seperti mengubah geometri lereng untuk mengurangi gaya penggerak, mengendalikan air permukaan (drainase) dan penambatan tanah (dengan bronjong, pasangan batu, tembok penahan, tiang pancang) untuk menambah gaya penahan, dan sebagainya. 
JURNAL KACAPURI

JURNAL KEILMUAN TEKNIK SIPIL

Volume 3 Nomor 1 Edisi Juni 2020

Berlatar belakang hal tersebut di atas, maka maksud dan tujuan dari penelitian ini adalah untuk membuat dan memperoleh desain penanggulangan keruntuhan lereng (longsoran) yang aman, relatif aman dan sesuai dengan kondisi di lapangan pada jalan di Desa Gunung Ulin, Kecamatan Pulau Laut Utara, Kabupaten Kotabaru.

\section{TINJAUAN PUSTAKA}

\section{Stabilitas Lereng}

Lereng adalah permukaan bumi yang membentuk sudut kemiringan tertentu dengan bidang horizontal. Lereng dapat terbentuk secara alamiah karena proses geologi ataukarena dibuat oleh manusia. Lereng yang terbentuk secara alamiah misalnya lereng bukit dan tebing sungai, sedangkan lereng buatan manusia antara lain yaitu galian dan timbunan untuk membuat jalan raya dan jalan kereta api, bendungan, tanggul sungai dan kanal serta tambang terbuka. Lereng umumnya terdapat di tepi jalan maupun di tebing sungai. Tebing yang berada di tepi jalan apabila lokasinya tidak memiliki resapan air yang baik dan dilewati beban transportasi secara terus-menerus, maka dapat menyebabkan terganggunya stabilitas lereng di tebing tersebut. Stabilitas lereng merupakan hal penting dalam ilmu geoteknik, karena apabila stabilitas lereng terganggu maka lereng rentan terhadap kelongsoran. Suatu longsoran adalah keruntuhan dari massa tanah yang terletak pada sebuah lereng sehingga terjadi pergerakan massa tanah ke bawah dan ke luar. Longsoran dapat terjadi dengan berbagai cara, secara perlahan-lahan atau mendadak serta dengan ataupun tanpa tanda-tanda yang terlihat. Dalam bidang teknik sipil ada tiga macam lereng yang perlu diperhatikan, yaitu sebagai berikut:

1. Lereng alam, yaitu lereng yang terbentuk karena proses alam, misalnya lereng suatu bukit.

2. Lereng yang dibuat dalam tanah asli. Misalnya bilamana tanah dipotong untuk pembuatan jalan atau saluran air untuk keperluan irigasi.

3. Lereng yang dibuat dari tanah yang dipadatkan. Misalnya tanggul untuk jalan atau bendungan tanah.

Pada setiap macam lereng ini kemungkinan terjadinya longsoran selalu ada. Tanah yang longsor itu bergerak pada suatu bidang tertentu. Bidang ini disebut bidang gelincir atau bidang geser (shear surface). Ada beberapa tipe keruntuhan lereng, antara lain sebagai berikut:

1. Kelongsoran Rotasi (rotational slip). Bentuk permukaan runtuh pada potongannya dapat berupa busur lingkaran atau kurva bukan lingkaran.

2. Kelongsoran Translasi (translasional slip). Permukaan runtuhnya berbentuk bidang dan hampir sejajar dengan lereng.

3. Kelongsoran Gabungan. Permukaan runtuhnya terdiri dari bagian-bagian lengkung dan bidang. 


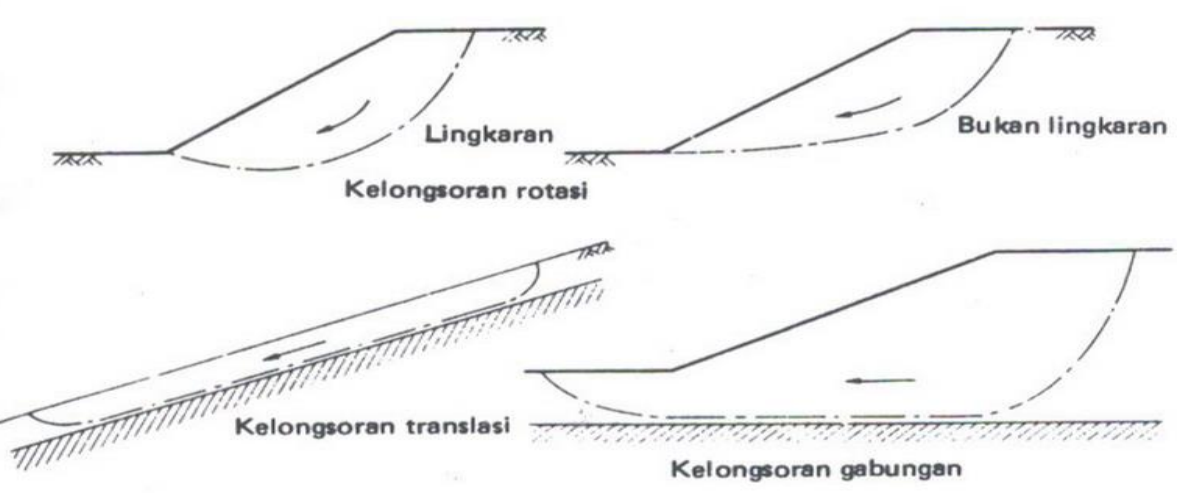

Gambar 1. Tipe - Tipe Kelongsoran Bidang (Craig, 1989)

Untuk mendapatkan hasil yang lebih teliti, maka dalam analisis stabilitas lereng pada penelitian ini digunakan Metode Alan W. Bishop (Simplified Bishop Method). Metode ini sama dengan metode Fellinius yaitu gaya-gaya yang bekerja pada sisi-sisi irisan resultannya nol pada arah vertikal bidang longsor, hanya saja dalam pemakaiannya agak rumit dan membutuhkan cara coba-coba (trial error) karena faktor aman nampak di kedua sisinya. Akan tetapi cara ini telah terbukti menghasilkan nilai faktor aman yang mendekati hasil hitungan dengan cara lain yang lebih teliti.

\section{Tekanan Tanah Lateral}

Tekanan tanah lateral adalah tekanan tanah arah horizontal yang merupakan gaya yang bekerja antara konstruksi penahan tanah dan massa tanah yang ditahan. Kestabilan konstruksi penahan tanah merupkan hasil mobilisasi dari tekanan tanah lateral pasif sebagai antisipasi dari tekanan-tekanan yang bekerja pada konstruksi penahan tanah tersebut, antara lain tekanan aktif dan tekanan residu air.

Tekanan tanah aktif (active earth pressure) adalah gaya yang cenderung mengurangi keseimbangan dinding penahan tanahnya. Nilai banding tekanan horizontal dan tekanan vertikal yang terjadi didefinisikan sebagai koefisien tekanan tanah aktif (coefficient of active earth pressure) atau $\mathrm{Ka}$. Nilai tekanan tanah aktif lebih kecil dari tekanan tanah saat diam (Harry Cristiady Hardiyatmo, 1994). Tekanan tanah pasif (passive earth pressure) adalah gaya yang mendorong dinding penahan tanah kearah tanah urugannya. Nilai banding tekanan horizontal dan tekanan vertikal adalah koefisien tanah pasif (coefficient of passive earth pressure) atau $K p$. Nilai tekanan tanah pasif lebih besar dari tekanan tanah saat diam atau tekanan tanah pasif.

Kestabilan konstruksi penahan tanah merupakan hasil mobilisasi dari tekanan tanah lateral pasif sebagai antisipasi dari tekanan - tekanan yang bekerja pada konstruksi penahan tahan tersebut, antara lain tekanan aktif dan tekanan residu air (perbedaan tinggi muka air). Tekanan tanah aktif dan tekanan tanah pasif adalah tekanan tanah dalam keadaan batas 
dimana tanah isian dibelakang mulai runtuh dan menggelincir karena berat sendiri atau keruntuhan gelincir (geser) mulai terjadi karena gaya dari dinding.

Metode yang digunakan untuk menentukan tekanan tanah aktif dan pasif dalam penelitian ini adalah metode Rankine (1857). Metode ini mempunyai anggapan yang pada pokoknya sama dengan anggapan yang digunakan oleh Coulomb, namun dalam analisisnya mengasumsikan bahwa:

a) Tanah dalam kedudukan keseimbangan plastis, yaitu sembarang elemen tanah dalam kondisi tepat runtuh.

b) Tanah urug didak berkohesi $(\mathrm{c}=0)$.

c) Gesekan antara dinding dan tanah urug diabaikan atau permukaan dinding dianggap licin sempurna $(\varsigma=0)$.

Tekanan tanah lateral menurut teori Rankine (1875) yaitu menganggap tanah dalam keadaan keseimbangan plastik dan mengasumsikan bahwa tidak ada kohesi tanah dan gesekan dinding (dinding licin).

\section{Prinsip Dasar Penanggulangan Longsoran}

Penanggulangan yang baik adalah penanggulangan yang dapat mengatasi masalah secara tuntas dan dengan biaya yang relatif murah serta mudah pelaksanaannya. Penanggulangan sangat tergantung pada tipe dan sifat longsoran, kondisi lapangan dan geologi.

Pada suatu lereng bekerja gaya-gaya yang terdiri dari gaya pendorong dan gaya penahan. Analisis kemantapan suatu lereng harus dilakukan dengan memperhitungkan besarnya gaya pendorong dan gaya penahan. Suatu lereng akan longsor apabila keseimbangan gayagaya yang bekerja terganggu, yaitu gaya pendorong melampaui gaya penahan. Oleh karena itu, ada 2 (dua) prinsip dasar penanggulangan kelongsoran, yaitu sebagai berikut:

1) Dengan memperkecil gaya penggerak atau momen penggerak, hal ini dapat dilakukan dengan beberapa cara, antara lain sebagai berikut:

a) Membuat lereng lebih datar; dan

b) Mengendalikan air permukaan (sistem drainase yang baik).

2) Memperbesar gaya melawan atau momen pelawan, hal ini dapat dilakukan dengan beberapa cara, antara lain sebagai berikut:

a) Dengan memakai "Counter weight", yaitu tanah timbunan pada kaki lereng;

b) Mengurangi tegangan air pori di dalam lereng;

c) Dengan cara mekanis, yaitu dengan memasang tiang atau membuat dinding penahan; dan

d) Dengan cara stabilisasi, dengan semen, kapur dan sebagainya.

\section{Penanggulangan Kelongsoran Dengan Menggunakan Tiang}

Tiang dapat digunakan baik untuk pencegahan maupun penanggulangan longsoran. Penggunaan tiang dimaksudkan untuk menambah momen penahan tanah. Bila tahanan tanah terhadap momen penggerak meningkat, berarti angka keamanan talud juga bertambah. Asumsi yang dipergunakan dalam konstruksi tiang dapat dilihat pada Gambar 2. Pada gambar tersebut kelompok tiang menerima gaya guling dari tanah. Untuk menentukan besarnya gaya horizontal yang terjadi adalah dengan membagi momen 
penggerak dengan lengan momen dan sudut antara bidang longsor dan tiang. Sudut didapatkan dengan menarik garis singgung yang mengenai bidang longsoran dan tiang terhadap garis horisontal. Penanggulangan longsoran yang terjadi bisa juga menggunakan tiang pancang, tiang bor, turap baja. Cara ini cocok untuk longsoran yang tidak terlalu dalam, tetapi penggunaan tiang ini terbatas oleh kemampuan tiang untuk menembus lapisan yang keras atau material yang mengandung bongkah-bongkah. Cara ini tidak cocok untuk gerakan tipe aliran, karena sifat tanahnya sangat lembek yang dapat lolos melalui sela tiang.

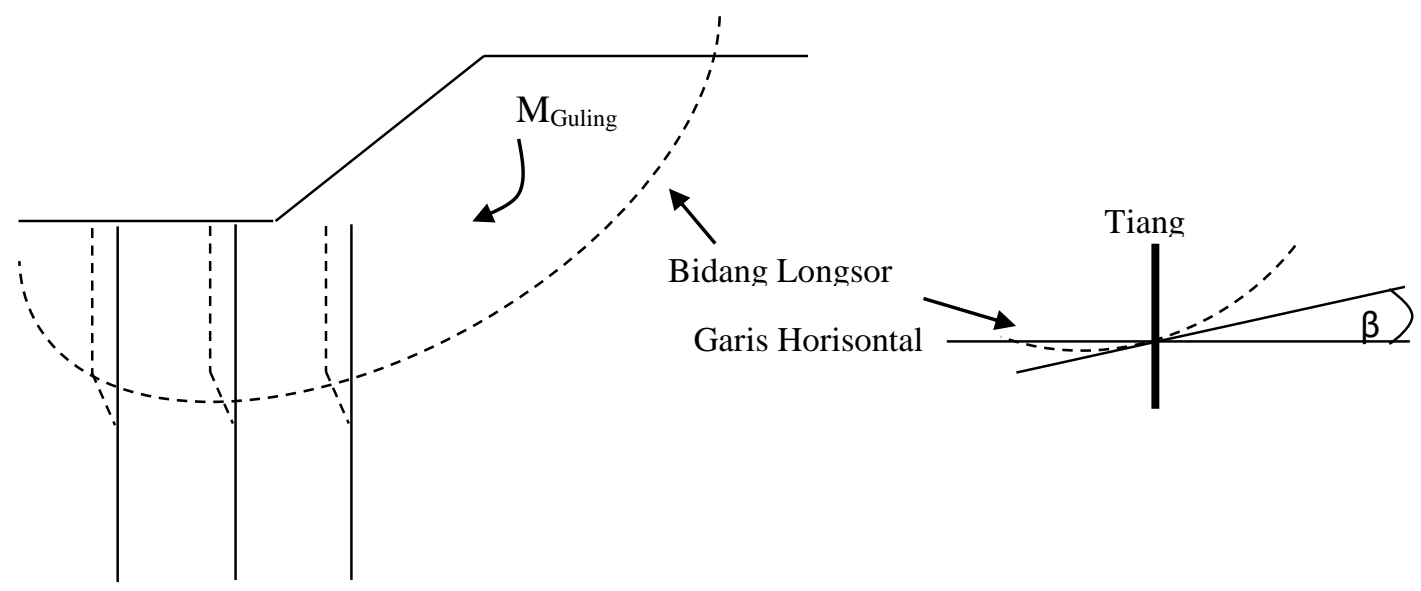

Gambar 2. Asumsi gaya yang diterima tiang (Dokumen Pribadi)

Untuk lapisan keras disarankan menggunakan tiang baja terbuka pada ujungnya atau tiang bor, walaupun demikian tiang bor mempunyai keterbatasan yang hanya dapat diterapkan pada longsoran yang relatif diam. Untuk penggunaan tiang pancang tidak disarankan untuk jenis tanah yang sensitif, karena dapat menimbulkan pencairan massa tanah sebagai akibat getaran pada pemancangan.

Pemakaian tiang baja tidak efektif untuk menahan longsoran yang besar, karena mempunyai modulus perlawanan yang kecil. Untuk itu tiang pipa baja dapat pula diisi beton atau komposit beton dengan baja profil untuk memperbesar modulus perlawanannya. Untuk menghitung kebutuhan tiang permeter, terlebih dahulu ditentukan besarnya momen penggerak dari bidang longsor yang akan ditahan. Kemudian menentukan jumlah baris dan besarnya dimensi tiang, agar diketahui besarnya tegangan geser tiang dan jarak antar tiang. Dan faktor keamanan didapat dengan membandingkan antara gaya geser antara tiang dan tanah di bawah bidang longsor $\left(\mathrm{S}_{\text {ada }}\right)$ dengan gaya geser antara tiang dan tanah pada bidang longsor $\left(\mathrm{S}_{\text {desain }}\right)$. Adapun prosedur perhitungan desain penanganan kelongsoran menggunakan tiang menurut Standar Nasional Indonesia 03 1962 - 1990 tentang Tata Cara Perencanaan Penanggulangan Longsoran adalah sebagai berikut : 


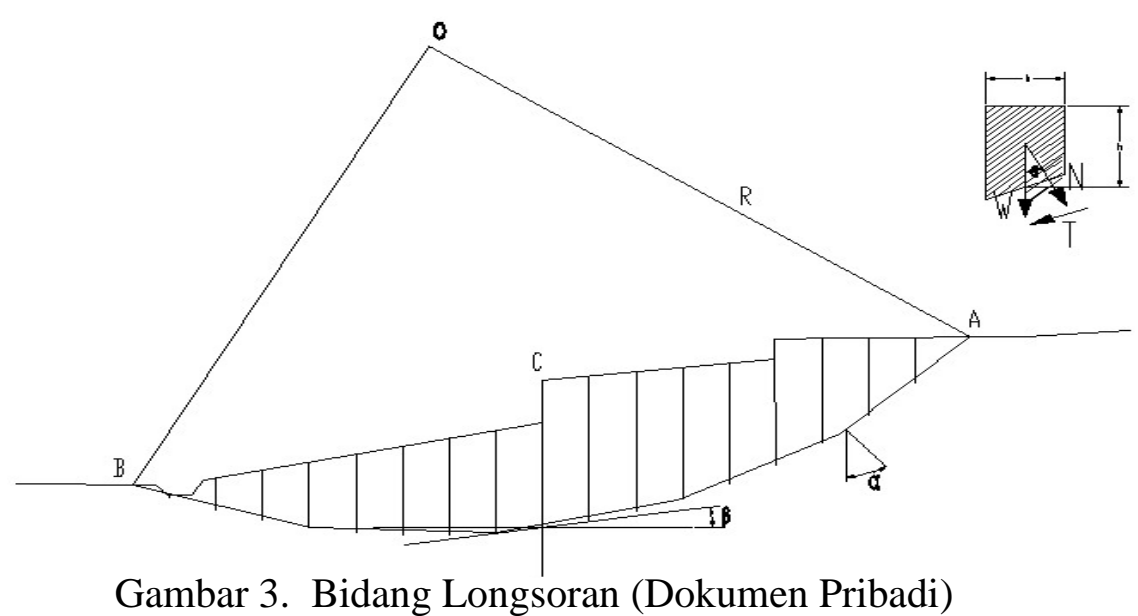

\section{METODE PENELITIAN}

Metode yang digunakan dalam penelitian ini terdiri dari dua tahapan yaitu inventarisasi data-data pendukung seperti data tanah yang didapatkan dari hasil penyelidikan tanah dan data geometri berupa data sekunder dari dokumen proyek yang meliputi : layout area longsor, potongan memanjang dan potongan melintang yang menggambarkan kondisi di lapangan. Kemudian, tahapan selanjutnya dilakukan analisa stablitas lereng dengan aplikasi program PLAXIS, yang hasil / outputnya digunakan dalam proses desain tiang dan dinding kantilever.

\section{Lokasi Penelitian}

Lokasi penelitian ini berada pada jalan di Desa Gunung Ulin, Kecamatan Pulau Laut Utara, Kabupaten Kotabaru.

\section{Data-Data Pendukung}

Data-data pendukung dalam penelitian ini adalah sebagai berikut:

a) Data hasil penyelidikan tanah meliputi data boring, data sondir dan data laboratorium;

b) Data geometri/profil (gambaran umum lokasi, penampang memanjang dan melintang terjadinya kelongsoran). Berfungsi untuk mengetahui deskripsi potongan kondisi lereng yang mengalami keruntuhan.

\section{Tahapan Analisis Stabilitas Lereng}

Data yang diperoleh akan dianalisa dengan menggunakan metode Alan W. Bishop secara komputerisasi melalui program PLAXIS V.8.2. Dengan menginput data - data tanah seperti berat volume tanah $\left(\gamma_{\text {tanah }}\right)$, kohesi $(c)$ dan sudut gesek dalam $(\phi)$. Dari hasil program PLAXIS V.8.2 ini nantinya akan didapat:

a) Faktor keamanan (SF),

b) Besarnya momen penggerak,

c) Jari-jari atau radius kelongsoran lereng,

d) Titik pusat kelongsoran, yang mana untuk selanjutnya dapat digunakan hasilnya dalam membuat perencanaan penanggulangan tersebut. 
JURNAL KACAPURI

JURNAL KEILMUAN TEKNIK SIPIL

Volume 3 Nomor 1 Edisi Juni 2020

\section{Bagan Alir Penelitian}

Bagan alir dari penelitian ini dapat dilihat pada Gambar 4 di bawah ini.

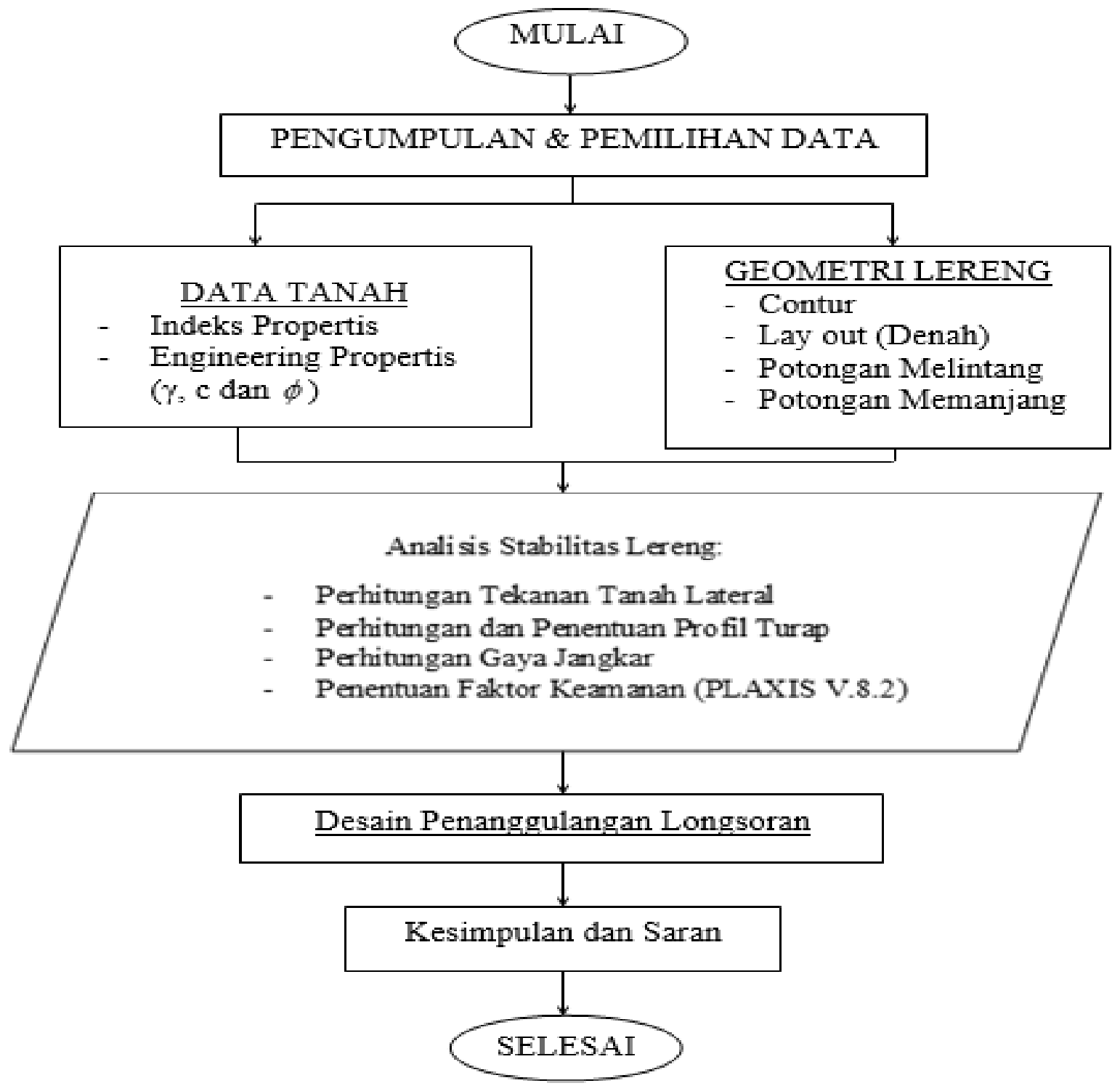

Gambar 4. Bagan Alir Penelitian

Sumber : Analisis, 2020 
JURNAL KACAPURI

JURNAL KEILMUAN TEKNIK SIPIL

Volume 3 Nomor 1 Edisi Juni 2020

\section{HASIL DAN PEMBAHASAN}

\section{Interpretasi Data Penyelidikan Tanah}

Penyelidikan lapangan yang dilakukan berupa sondir. Jumlah titik pada penyelidikan lapangan ini terdiri dari 2 (dua) titik penyondiran. Kedua titik penyondiran tersebut tepat berada di garis kelongsoran. Dalam kajian ini data sondir yang digunakan adalah data sondir pada titik satu (S1), tanah keras berada pada kedalaman 10,20 m dan sondir pada titik dua (S2) tanah keras berada pada kedalaman 9,8 m, sehingga diambil kedalaman terbesar 10,2 m.

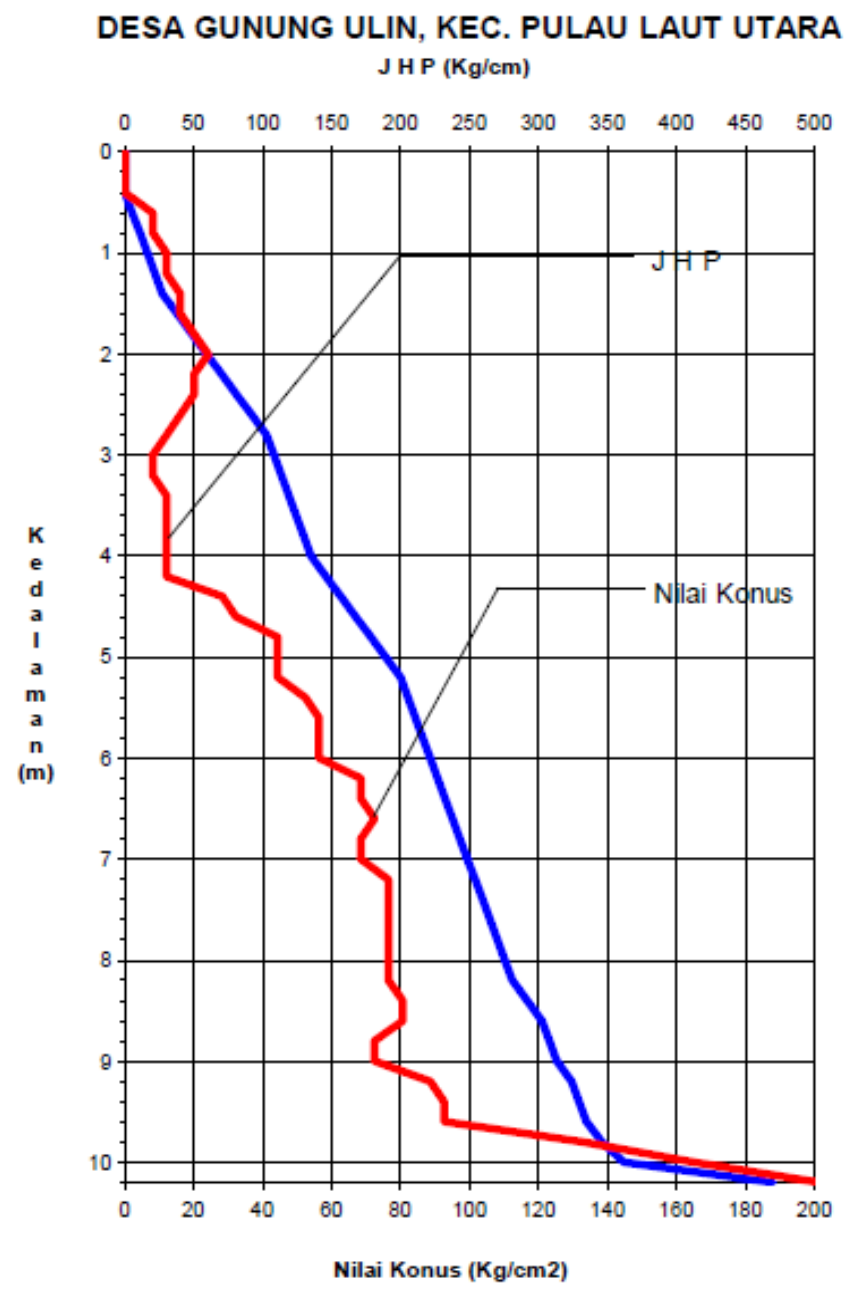

(a)
JUNG ULIN, KEC. PULAU LAUT UTARA $\mathrm{J}$ H P $(\mathrm{Kg} / \mathrm{cm})$

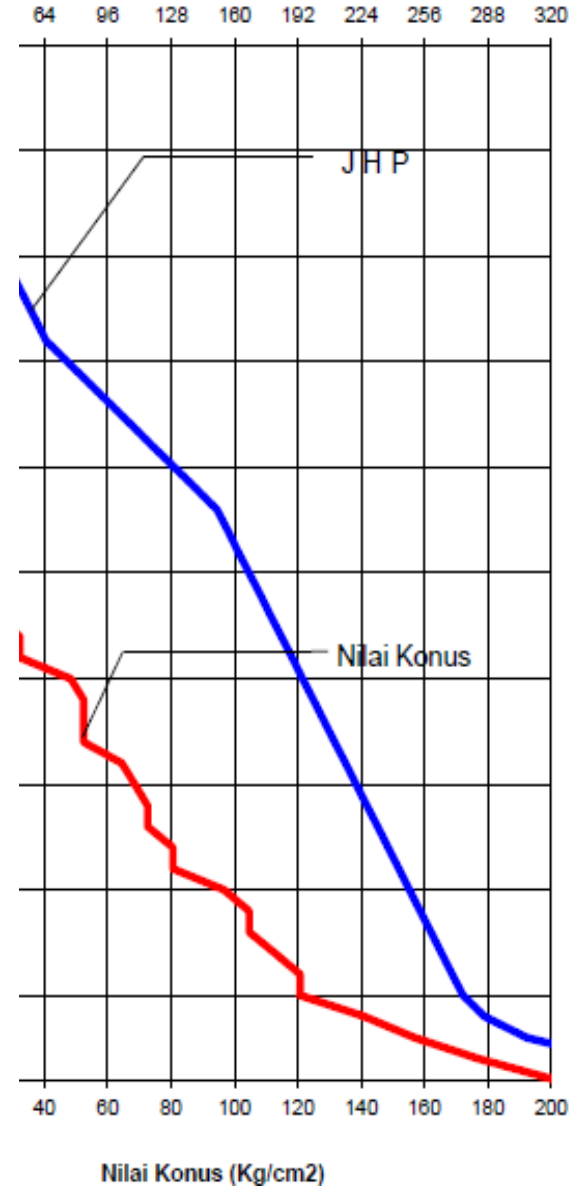

(b)

Gambar 5. Grafik Uji Penetrasi Konus (a) Sondir 1 (b) Sondir 2 
JURNAL KACAPURI

JURNAL KEILMUAN TEKNIK SIPIL

Volume 3 Nomor 1 Edisi Juni 2020

Tabel 1. Hasil Summary Uji Laboratorium

\begin{tabular}{|c|c|c|}
\hline Sample No. & & $:-$ \\
\hline Depth & & $:-1,00 \mathrm{~m} \mathrm{~s} . \mathrm{d}-1,50 \mathrm{~m}$ \\
\hline Specific Gravity & & 2.55 \\
\hline Water content & $\%$ & 28.18 \\
\hline Volumetric weight & $\mathrm{gr} / \mathrm{cm}^{-}$ & 1.81 \\
\hline \multicolumn{3}{|c|}{ Grain Distribution } \\
\hline Gravel (>2 mm) & $\%$ & 0.48 . \\
\hline Course sand $(0.6-2.0 \mathrm{~mm})$ & $\%$ & 0.69 \\
\hline Medium sand $(0.2-0.6 \mathrm{~mm})$ & $\%$ & 1.15 \\
\hline Fine sand $(0.05-0.2 \mathrm{~mm})$ & $\%$ & 2.71 \\
\hline Silt and Clay $(0.002-0.05)$ & $\%$ & 16.70 \\
\hline Clay $(<0.002 \mathrm{~mm})$ & $\%$ & 78.27 \\
\hline \multicolumn{3}{|c|}{ Atterberg Limits } \\
\hline Liquid limit & $\%$ & 55.00 \\
\hline Plastic limit & $\%$ & 24.35 \\
\hline Plasticity Index & $\%$ & 30.65 \\
\hline \multicolumn{3}{|c|}{ Direct shear test } \\
\hline $\bar{c}$ & $\mathrm{~kg} / \mathrm{cm}^{2}$ & 0.400 \\
\hline$T_{\phi}$ & 0 & 18.17 \\
\hline Vane shear test $\left(\mathrm{s}_{\mathrm{v}}\right)$ & $\mathrm{kPa}$ & $>130$ \\
\hline \multicolumn{3}{|c|}{ Unconfined compression test } \\
\hline qu & $\mathrm{kg} / \mathrm{cm}^{2}$ & 0.93 \\
\hline$\varepsilon$ & $\%$ & 10.00 \\
\hline Sensitivity & & 1.33 \\
\hline \multicolumn{3}{|c|}{ Consolidation test } \\
\hline$\overline{\mathrm{C}_{\mathrm{c}}}$ & & 0.374 \\
\hline $\mathrm{C}_{\mathrm{s}}$ & & 0.048 \\
\hline$C_{\mathrm{v}}$ & $\mathrm{cm}^{2} / \mathrm{sec}$ & 6.9.E-04 \\
\hline
\end{tabular}

\section{Perhitungan Tekanan Tanah Lateral}

Pada perhitungan ini terlebih dahulu yang dilakukan adalah membuat diagram tegangan, sehingga didapat batas keruk dan panjang turap. Pada perancangan turap pada tanah kohesif, kuat geser tanah lempung akan berubah dengan waktunya, sehingga tekanan tanah lateral juga akan berubah. Untuk itu tekanan tanah dihitung berdasarkan kuat geser undrained dengan mengasumsikan kondisi tanah lempung dalam kondisi lumayan keras dengan nilai $\varphi=\mathbf{1 8 , 1 7}$.
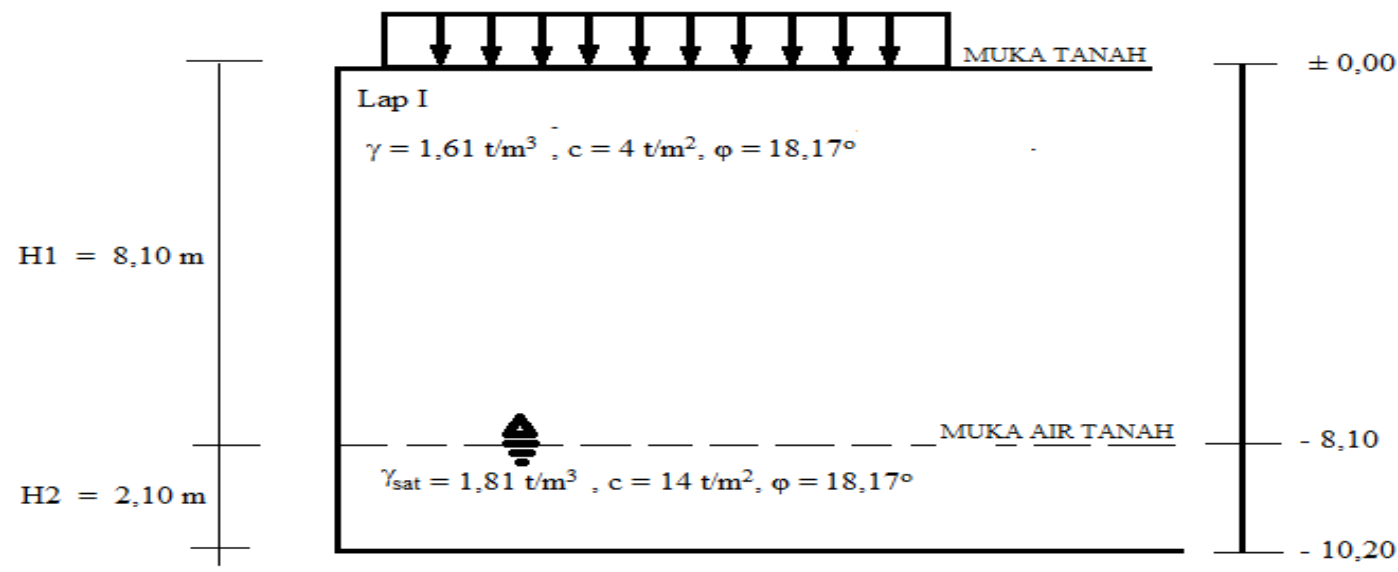

Gambar 6. Penampang Struktur Lapisan Tanah 


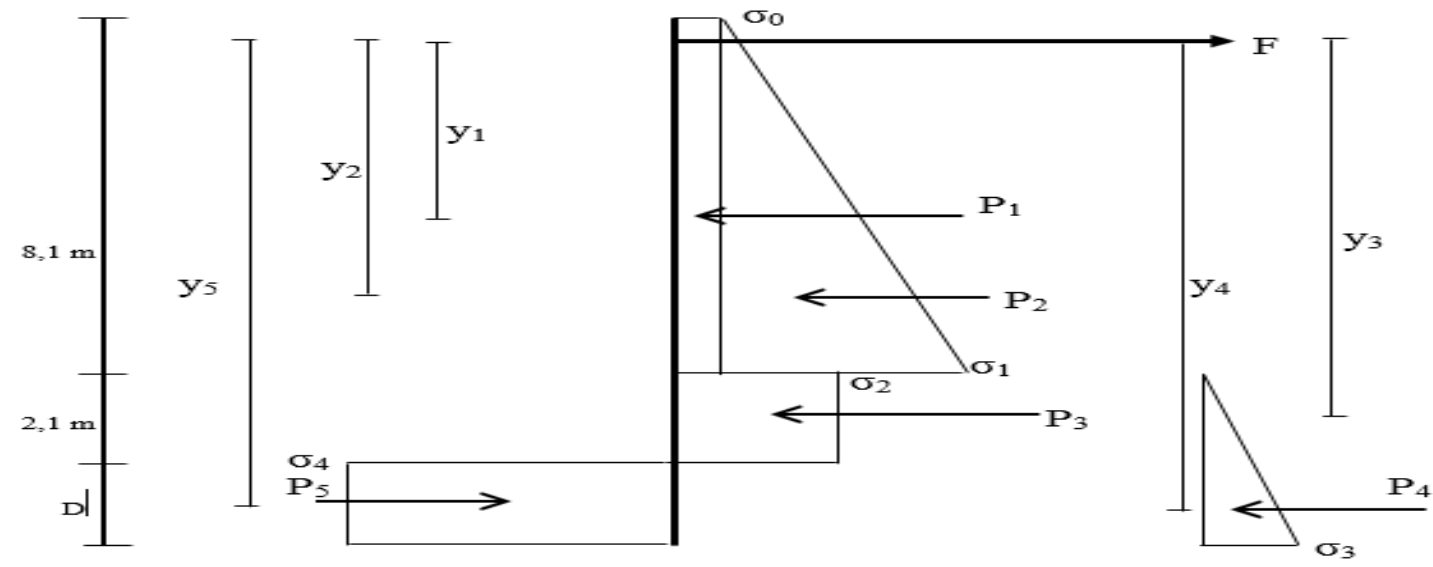

Gambar 7. Diagram Tekanan Tanah Lateral

\section{Analisis Stabilitas Lereng}

Dilihat dari analisa keruntuhan terhadap lereng jalan Desa Gunung Ulin, Kecamatan Pulau Laut Utara, Kabupaten Kotabaru menggunakan aplikasi program PLAXIS V.8.2 maka akan didapatkan nilai Safety Factor (SF) < 1,5 yaitu 1,407. Bidang kelongsoran dan safety factor-nya dapat dilihat pada gambar 8 di bawah ini.

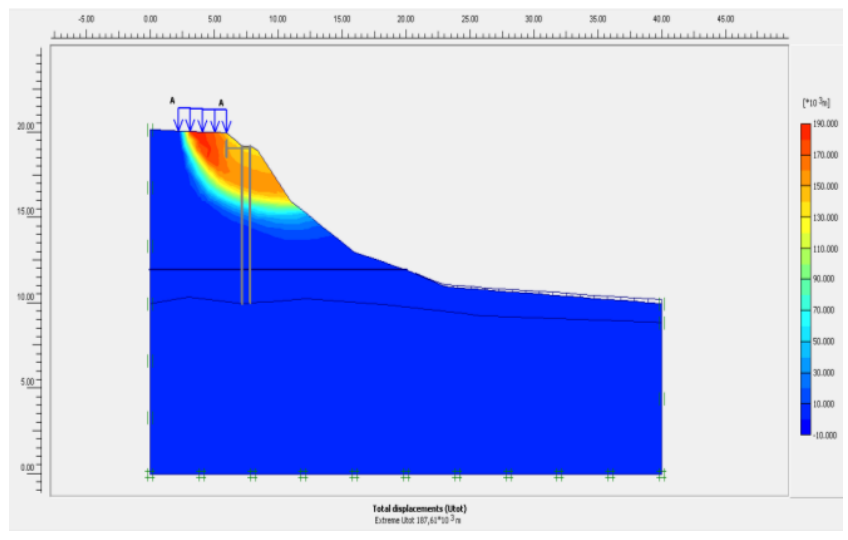

(a) Bidang Kelongsoran Lereng Lereng

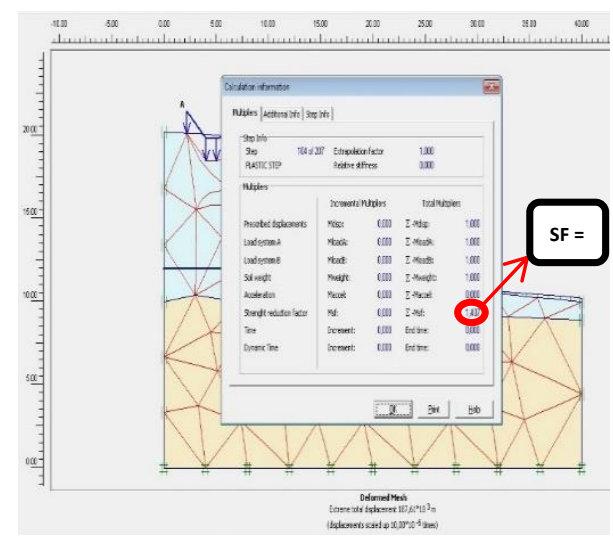

(b) Faktor Keamanan Kelongsoran

Gambar 8. Hasil Analisis Stabilitas Lereng pada Kondisi Eksisting

Berdasarkan hasil analisis di atas, dapat diketahui bahwa lereng mengalami kelongsoran dan perlu dilakukan penanggulangan terhadap longsoran tersebut. Selanjutnya dilakukan analisis perhitungan menggunakan alternatif penanganan yaitu pemasangan turap baja bentuk kotak jenis FSP VIL (Profil A dan B). Berdasarkan hasil perhitungan diperoleh panjang total turap 10,7 meter dari permukaan tanah dan untuk menahan gaya lateral digunakan jangkar sepanjang 7,2 meter dengan diameter jangkar sebesar $3 \mathrm{~cm}$. Dalam analisis secara manual ini diperoleh kesimpulan bahwa dengan pemasangan turap tersebut dapat menanggulangi kelongsoran dan lereng dapat dinyatakan aman. Selanjutnya hasil 
analisis ini di input ke dalam program PLAXIS V.8.2 untuk memperoleh nilai faktor keamanan setelah dilakukan perkuatan turap dan jangkar.

Berdasarkan hasil analisa perhitungan dengan program PLAXIS V.8.2 dapat disimpulkan bahwa pemancangan turap dengan panjang 10,7 $\mathrm{m}$ dan jangkar dengan panjang 7,2 $\mathrm{m}$ sudah memenuhi syarat dan dapat dikatakan aman dengan Safety Factor (SF) > 1,5 yaitu 5,277 , bidang kelongsoran lereng dan safety factor nya dapat dilihat pada gambar 9 di bawah ini.

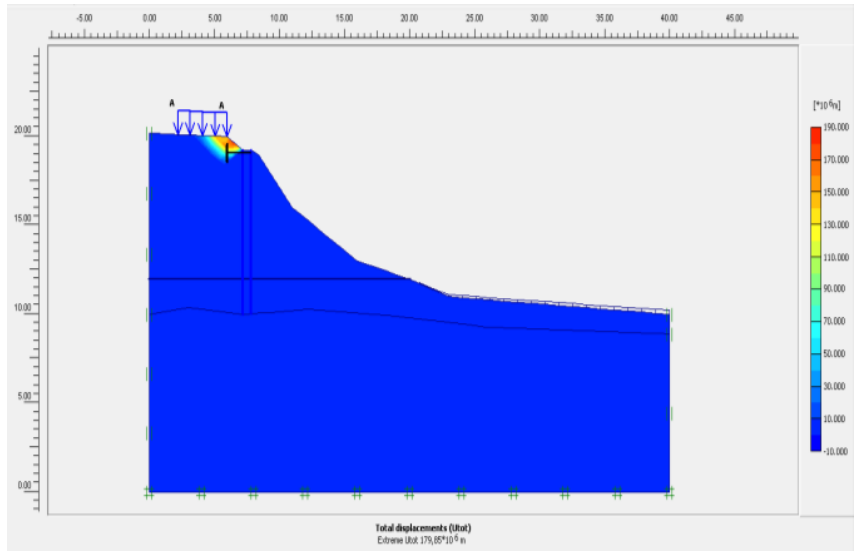

(a) Bidang Kelongsoran Lereng Lereng

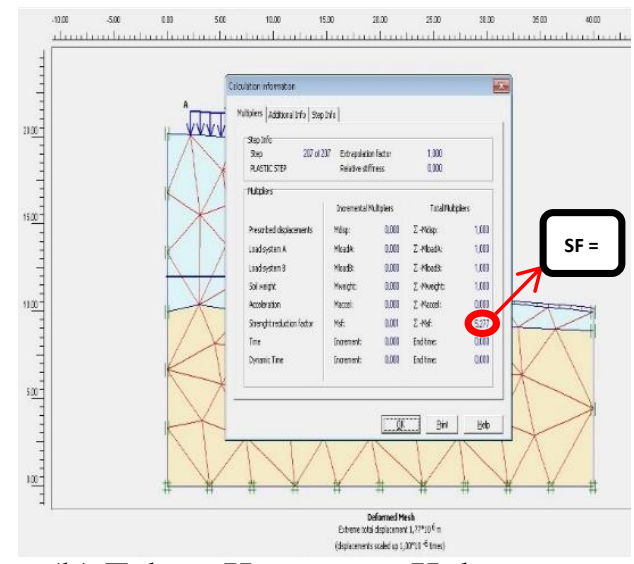

(b) Faktor Keamanan Kelongsoran

Gambar 9. Hasil Analisis Stabilitas Lereng Setelah Dilakukan Perkuatan Turap dan Jangkar

\section{Kesimpulan}

\section{PENUTUP}

Berdasarkan hasil analisis stabilitas lereng dan analisa perhitungan turap baja pada lereng di Desa Gunung Ulin, Kecamatan Pulau Laut Utara, Kabupaten Kotabaru dapat disimpulkan sebagai berikut:

1. Dari hasil analisa stabilitas lereng menggunakan program PLAXIS V.8.2 didapatkan Safety Factor (SF) kondisi awal (eksisting) lereng tidak aman terhadap kelongsoran yaitu dengan $\mathrm{SF}<1,5$ yaitu 1,407.

2. Untuk menanggulangi kelongsoran lereng tersebut maka kami melakukan analisa perhitungan turap yang aman. Dengan konstruksi berupa:

a) Turap baja profil kotak: profil $\mathrm{A}=$ FSP VIL dan profil $\mathrm{B}=$ FSP VIL dengan kedalaman

b) dapat dikatakan aman pemancangan sepanjang 10,7 m.

c) Untuk menahan gaya lateral pada turap baja maka digunakan jangkar yang direncanakan sejauh 7,2 m.

Dari hasil analisis program PLAXIS V.8.2 dapat disimpulkan bahwa dalam pemancangan turap dan panjang jangkar rencana karena telah melewati garis kelongsoran dengan Safety Factor $(\mathrm{SF})>1,5$ yaitu 5,277 . 
JURNAL KACAPURI

JURNAL KEILMUAN TEKNIK SIPIL

Volume 3 Nomor 1 Edisi Juni 2020

\section{Ucapan Terimakasih}

Penulis mengucapkan terimakasih kepada kawan-kawan dosen Universitas Islam Kalimantan Muhammad Arsyad Al Banjari Banjarmasin dan semua pihak yang telah banyak membantu kelancaran dan selesainya penelitian ini.

\section{DAFTAR PUSTAKA}

Bowles, Joseph E. (1981). Analisa dan Disain Pondasi ( jilid 2). Erlangga. Jakarta.

Das, B. M. (1998). Mekanika Tanah (Prinsip-prinsip Rekayasa Geoteknis) Jilid 2. Erlangga. Jakarta.

Craig, R. F., (1989). Mekanika Tanah Jilid 4. alih bahasa oleh Soepandji, B. S. Erlangga. Jakarta.

Gazali, Akhmad. (2016). Analisis Stabilitas Lereng Dan Penanggulangan Kelongsoran Lereng Pada Ruas Jalan Abdul Azis Karias (Pasar Amuntai), Kabupaten Hulu Sungai Utara. Program Studi Teknik Sipil Universitas Islam Kalimantan Muhammad Arsyad Al Banjari. Banjarmasin.

Gazali, Akhmad. (2019). Analisis Penanggulangan Longsoran Pada Tepi Timbunan Jalan Menggunakan Perkuatan Dinding Turap Galam Di Daerah Rawa Kabupaten Barito Kuala. Program Studi Teknik Sipil Universitas Islam Kalimantan Muhammad Arsyad Al Banjari. Banjarmasin.

Indrasurya. Prof. Dr. Ir. (2000). Teknologi Perbaikan Tanah dan Alternatif Perencanaan pada Tanah Bermasalah. Jurusan Teknik Sipil FTSLK-ITS. Surabaya.

M, J.Smith.(1984). Mekanika Tanah (Soil Mechanics) Edisi keempat. Erlangga. Jakarta.

Murthy, V. N. S. Geotechnical Engineering Principle and Practices of Soil Mechanics and Foundation Engineering. Basel. Newyork.

Pradoto, Suhardjito. Dr. Ir. (1989). Teknik Fundasi. Lab Geoteknik Pusat Antar Universitas Ilmu Rekayasa ITB. Bandung.

PU, (1987). Petunjuk Perencanaan Penanggulangan Longsoran. PU. Jakarta.

Sunggono. (1984). Mekanika Tanah. Nova. Bandung.

Wiratni, N. E. (2009). Perencanaan Kelongsoran Dengan Menggunakan Turap Di Halaman Pasar Negara Kecamatan Daha Selatan Kabupaten Hulu Sungai Selatan Kalimantan Selatan. Skripsi S1 Geoteknik. FT. UNLAM. Banjarbaru. 